УДК 633:[620.925.58]:631.559:631

(C) 2018

Курило В. Л., доктор сільськогосподарських наук, професор

Національна академія аграрних наук України

Рахметов Д. Б., доктор сільськогосподарських наук, професор

Національний ботанічний сад імені М. М. Гришка НАН України

Кулик М. І., кандидат сільськогосподарських наук, доцент

Полтавська державна аграрна академія

\title{
БІОЛОГІЧНІ ОСОБЛИВОСТІ ТА ПОТЕНЦІАЛ УРОЖАЙНОСТІ ЕНЕРГЕТИЧНИХ КУЛЬТУР РОДИНИ ТОНКОНОГОВИХ В УМОВАХ УКРАЇНИ
}

Рецензент - доктор сільськогосподарських наук, професор М. Я. Шевніков

Обтрунтовано необхідність всебічного вивчення та вирощування енергетичних культур на маргінальних землях в умовах України для отримання біопалива. Наведено біолого-морфологічну характеристику та ілюстративний матеріал енергетичних культур з родини тонконогових. Розуміння морфологобіологічних особливостей та відношення енергетичних культур до умов навколишнього середовище дасть змогу раціонально розмімувати їх у певних трунтово-кліматичних зонах України, підбирати оптимальні елементи технології вирощування. Це забезпечить умови, близькі до сприятливих для росту $i$ розвитку рослин, та дозволить отримувати велику, енергосмну фітомасу. Визначено, щзо найбільиу врожайність сухої маси формує арундо тростинний та міскантус гігантський, меншу - сорго багаторічне та просо прутоподібне за багаторічного ицилу вирощування в грунтово-кліматичних умовах, щзо відповідають їх біологічним особливостям. Урожай фітосировини енергетичних культур доцільно використати для виробництва біопалив та отримання енергї.

Ключові слова: енергетичні культури, ботанічна характеристика, біологічні особливості, урожайність, енергетична продуктивність.

Постановка проблеми. На сьогоднішній день головними пріоритетами нової галузібіоенергетики - є пошук шляхів здешевлення різних видів біосировини, розробка нових техніко-економічних рішень, а також формування необхідної інфраструктури з метою ефективнішого використання рослинних енергетичних ресурсів i переробки їх фітомаси для отримання рідкого (біоетанол, біобутанол), газоподібного та твердого біопалива (гранули, брикети тощо).

Для реалізації програми розвитку біоенергетики в Україні наявні всі необхідні передумови, в першу чергу - грунтово-кліматичні умови, які сприяють отриманню високої врожайності енергоємної фітомаси енергетичних культур. Подруге, використання адаптивних технологій вирощування на маргінальних землях біоенергети- чних культур, вдосконалення існуючих, відповідна переробка фітосировини й використання біопалива в ПЕК (паливо-енергетичному комплексі) забезпечить зростання частки біоенергетики у загальній структурі енергетики України та значно зменшить енергозалежність нашої країни. Як результат - зменшення використання непоновлюваних енергоресурсів на фоні зростання попиту на альтернативні джерела енергії, що в перспективі сприятиме розвитку національної економіки та зростанню добробуту населення.

Енергетична стратегія України до 2030 року [4] передбачає динамічне зростання обсягів використання енергіï біомаси в 2015 р. до 5 млн тонн умовного палива (т у. п.), або це 2,5 \% від загального енергоспоживання, а в 2030 році - до 20 млн т у. п., або до $10 \%$.

Окрім цього Закон України «Про альтернативні джерела енергії» із внесеними змінами [8] визначає основні засади державної політики у сфері альтернативних джерел енергії, одним 3 якими $\epsilon$ : нарощування обсягів виробництва та споживання енергії, виробленої 3 альтернативних джерел, 3 метою економного витрачання традиційних паливно-енергетичних ресурсів та зменшення залежності України від їх імпорту шляхом реструктуризації виробництва і раціонального споживання енергії за рахунок збільшення частки енергії з відновлювальних джерел.

Поряд із цим, у секторі електроенергії з біомаси ситуація змінюється після введення нового порядку розрахунку згідно «зеленого» тарифу на електроенергію, вироблену 3 відновлюваних джерел енергії. Цей порядок розрахунку висвітлений у Законі України «Про внесення змін до Закону України «Про електроенергетику» щодо стимулювання використання альтернативних джерел енергії» [7], та Постанови НКРЕ «Про затвердження Порядку встановлення, перегляду та припинення дії «зеленого» тарифу для 


\section{СІЛЬСЬКЕ ГОСПОДАРСТВО. РОСЛИННИЦТВО}

суб' єктів господарської діяльності» [20].

Все це, на нашу думку, обумовлює актуальність обраного напряму дослідження.

Аналіз основних досліджень i публікацій, у яких започатковано розв'язання проблеми. Вивченню енергетичних культур в умовах нашої країни присвячена значна кількість наукових праць: М. В. Роїка, В. Л. Курила, М. Я. Гументика [24], О. М. Ганженка [13], Д. Б. Рахметова [22], Д. Б. Рахметова і О. М. Вергуна [23], Г. Г. Гелетухи, Т. А. Железної, О. В. Трибой [2], Г. С. Гончарука, С. М. Мандровської [25], М. І. Кулика [30] та ін.

3-поміж енергетичних культур в Україні найбільшого поширення набули: просо прутоподібне (світчграс), верба, міскантус, тополя. Тривалість їхнього життя - 10-15, інколи - до 30 років, агрозаходи для їх вирощування не вимагають значних затрат, збір урожаю проводять зимою чи навесні, використовуючи звичайну сільськогосподарську техніку $[5,14,17,21]$. Поряд із цими культурами науковий інтерес мають наступні: арундо тростинний [28-29], сорго цукрове та багаторічне. Але детальному вивченню морфо-біологічних особливостей цих культур, потенціалу їхньої врожайності та енергопродуктивності не приділялося належної уваги.

Г. М. Калетнік у монографії [9] систематизував науково-методичні та організаційноекономічні основи формування ринку біопалив, створення та розвитку ринку енергетичних культур, які використовуються як сировина при виробництві біопалив, техніко-технологічні характеристики виробництва біопалива із сировини рослинного походження, а також надав економічну оцінку їхнього застосування агропромисловим комплексом України. Проведене автором узагальнення світових тенденцій розвитку ринку біопалива із сировини рослинного походження, дозволило розробити економічне обгрунтування перспектив подальшого розвитку українського ринку біопалив.

Вивчення енергетичних культур, за виключенням окремих публікацій, в основному стосується урожайного та енергетичного потенціалу, можливості отримання біопалива з їхньої біомаси, без урахуванням ботаніко-біологічних особливостей даних культур та можливості їхнього районування по грунтово-кліматичних зонах України для більш повної реалізації потенціалу культур з метою отримання максимального виходу біопалива із біомаси рослин.

Для вирішення даної проблеми, на основі наявної інформації та результатів власних напрацю- вань, ми наводимо узагальнену морфологобіологічну характеристику рослин, ілюстративний матеріали енергетичних культур із родини тонконогових. Проведено оцінку потенціалу їх урожайності, енергетичної та біопаливної продуктивності і можливості культивування в різних грунтовокліматичних зонах України.

Мета досліджень - охарактеризувати видову та сортову різноманітність, морфологічні особливості та відношення енергетичних культур родини тонконогових до умов навколишнього середовища для реалізації потенціалу рослин щодо їх урожайності та енергетичної продуктивності.

Відповідно до поставленої мети досліджень передбачалося вирішення наступник завдань:

1. Узагальнити наявну інформацію щодо морфологічних особливостей енергетичних культур, відношення їх до умов навколишнього середовища;

2. Визначити потенціал урожайності біомаси енергетичних культур та енергетичну продуктивність на одиницю площі;

3. Розглянути можливості розподілу енергетичних культур по грунтово-кліматичних умовах, що відповідають їх біологічним особливостям.

Матеріали та методика досліджень. Під час виконання досліджень за зазначеною темою використовували загальноприйняті методики проведення досліджень [3, 6], визначники, бібліотечні каталоги, альбоми [10, 12, 19], атласи [1], довідники [11] та спеціальні методичні рекомендації $[15,26]$. Енергетичну цінність сировини визначали на калориметрі ICO 200. Енергетичну продуктивність рослин визначали на основі теплоємності та урожайності фітосировини з урахуванням методик $[16,18]$.

Результати досліджень. Енергетичні культури родини тонконогових різняться між собою за тривалістю вегетаційного періоду, інтенсивністю росту і розвитку, формою, забарвленням продуктових органів та їх будовою, відношенням до умов навколишнього середовища, технологією вирощування і особливостями збирання врожаю біомаси. Наводимо ілюстративний матеріали (рис. 1-5) та морфолого-біологічні особливості енергетичних рослин.

Арундо тростинний (Arundo donax L.), або очерет гігантський - багаторічна рослина 3 родини тонконогових, з високими (до 8 м) прямими стеблами, дуже жорсткими і дерев'янистими, а всередині порожнистими і трубчастими, діаметром до 5 см. Рослина формує короткі, дерев'янисті кореневища. 

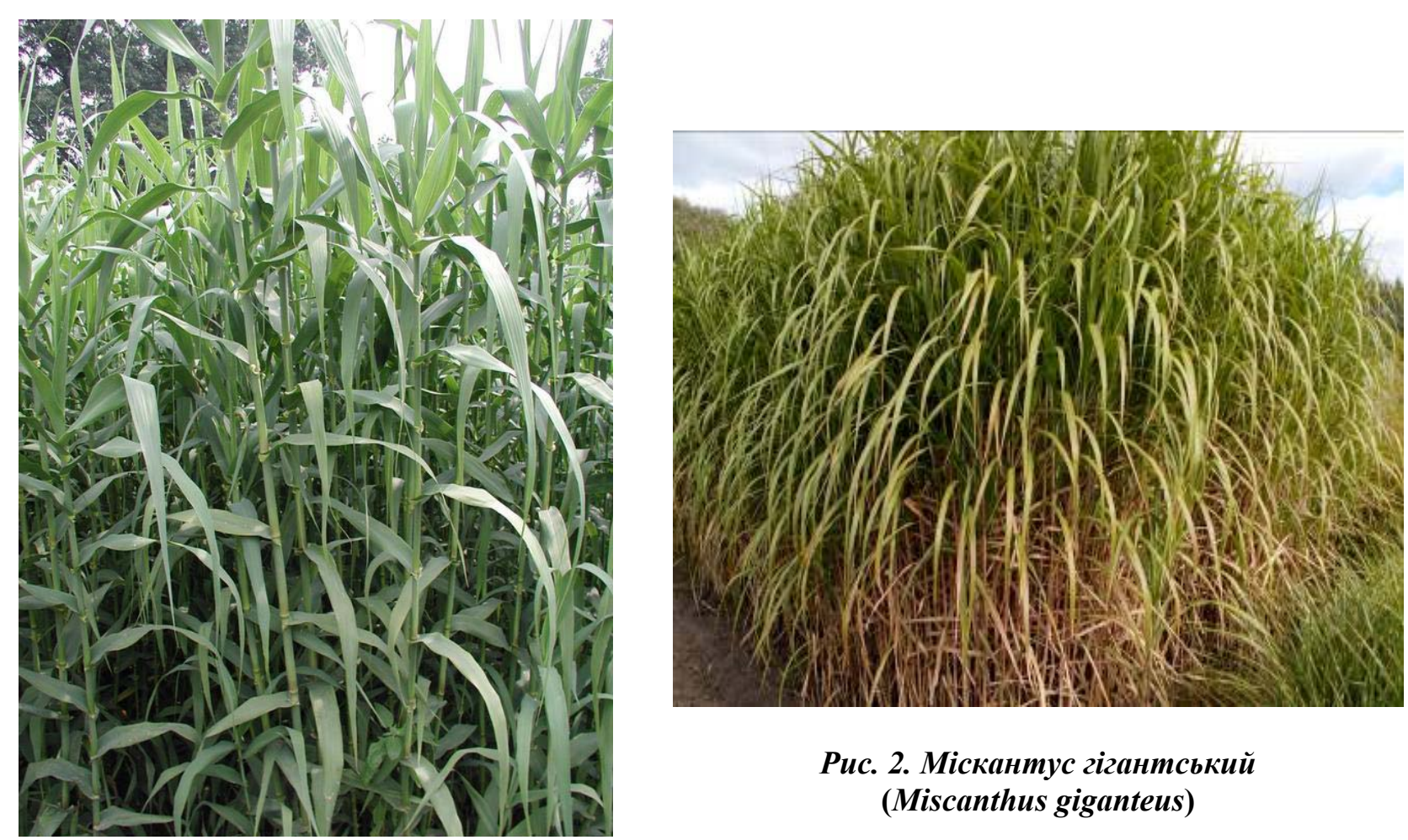

Рис. 2. Міскантус гігантський (Miscanthus giganteus)

Рис. 1. Арундо тростинний (Arundo donax L.)

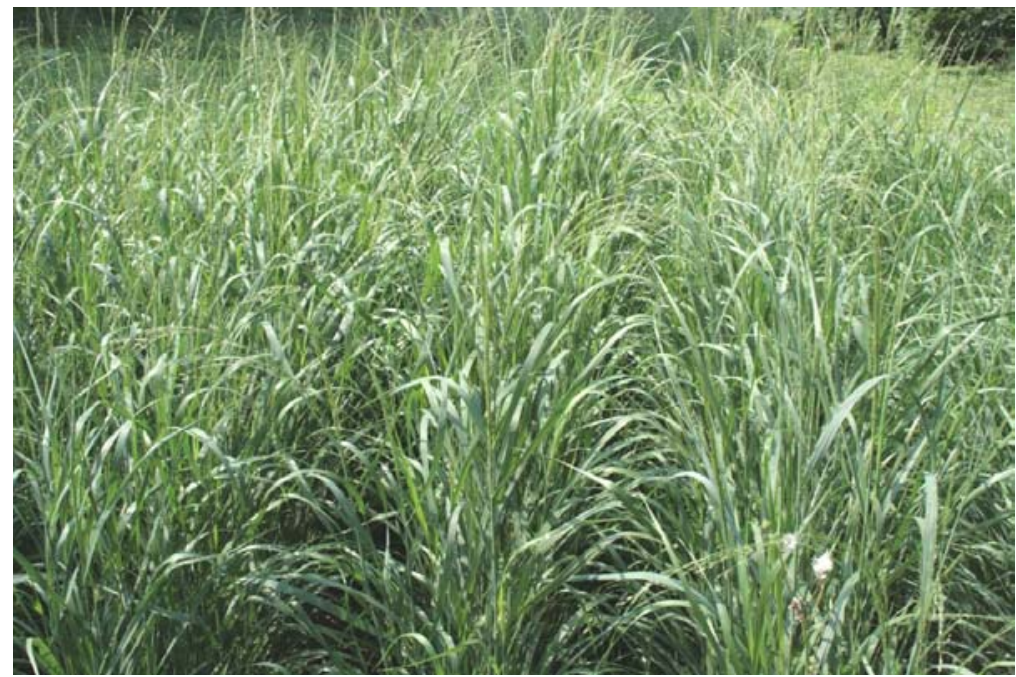

Puc. 3. Просо прутоподібне (Panicum virgatum L.)

Листки - вузькі, довгі, лінійно-ланцетні, не опушені. Квіти дрібні, зібрані у густу, пухнасту волоть, яка складається 3 безлічі дрібних колосків по 2-7 квіток, в яких формується нежиттєздатне насіння.

Температура відростання нових пагонів навесні становить $7^{\circ} \mathrm{C}$, оптимальна для вегетації рослин $-30{ }^{\circ} \mathrm{C}$.

Урожайність фітомаси - від 25 до 50 т/га.

Енергопродуктивність рослин - до 100 Гкал/га.

Міскантус гігантський $(M . \times$ giganteus $)$ - це тетраплоїдний гібрид міскантусу китайського
(M. sinensis Anderss.) і міскантусу цукроквіткового (M. sacchariflorus (Maxim.) Benth). Багаторічна трав'яниста рослина $3 \mathrm{C}_{4}$-схемою фотосинтезу.

Рослини досягають висоти 220-310 (може до 450-500) см. Число пагонів в кущі становить 10 15 (до 70). Стебло пряме, округле. Діаметр стебла - 12-25 мм. Число листків на стеблі - 11-15 штук, ширина їх - 2,2-2,9 см, довжина - 93102 см. Волоть має веретеноподібну, конусоподібну або еліпсоподібну форму і досягає в довжину 30-33 см. Рослини мають рихлокущовий тип кущіння. Число кореневищ (ризом) у одній 
рослині становить від 18 до 37 шт., довжина їх 10-15 см.

Відростання пагонів навесні розпочинається 3 другої половини квітня, кущіння - кінець червня, вихід у трубку - кінець серпня. Вегетація завершується в фазі появи волоті (найчастіше в фазі виходу в трубку) у першій половині жовтня. Життєвий цикл рослин триває 15-20 років.

Урожайність зеленої фітомаси становить від 60 до 150 т/га, сухої маси - 10-15 (до 32) т/га. Енергетична продуктивність рослин становить 67-84 (до 130) Гкал/га.

Просо прутоподібне (Panicum virgatum L.) багаторічна трав'яниста рослина (до 10-15 років на одному місці).

Рослини досягають висоти від 100-150 до 210250 см. Число продуктивних пагонів на рослині становить від 12-14 до 30-35 штук. Рослини залежно від форми бувають прямі і напіврозлогі. Число метамерів на стеблі становить від 3 до 7, а у окремих форм - до 9. Діаметр у основі стебла в середньому становить 4-6 мм, але зустрічаються форми 3 тонкими і товстими стеблами. Листкова пластинка досягає довжини 50-60 см, у деяких форм може бути значно довшою; ширина - в середньому 11-14 мм. За формою волоть буває розлогою, комоподібною, овальною, пірамідальною, стислою. Довжина волоті становить 30-40 см, ширина - 20-30 см. За масою 1000 шт. зернівки поділяють на три групи: 3 малою масою - до 1,5 г, iз середньюю масою - 1,5-1,8 і $з$ великою масою понад 1,8 г. Багаторічні кореневища при вегетативному розмноженні можна розділити на 8-25 (до 80) частин залежно від року життя і форми рослин. Кожна посадкова одиниця має довжину 5-7 см.

На відміну від більшості багаторічників, просо багаторічне проходить повний цикл розвитку (від насіння до насіння) протягом першого веге- таційного періоду. Завершує інтенсивну вегетацію в III декаді серпня - кінці жовтня залежно від генотипу. Після перезимівлі, рано навесні (II декада квітня) починається інтенсивне відростання рослин. Фаза виходу в трубку настає 3 другої декади липня. Цвітіння проходить 3 третьої декади липня до першої декади серпня. Достигання - кінець вересня - середина жовтня. Вегетаційний період - 175-185 діб.

Урожайність надземної фітомаси рослин в період появи волоті становить 42-64 т/га, в період цвітіння - 42,7-70,2 т/га; сухої маси - 10-15 т/га; насіння - 500-600 (іноді до 1000) кг/га. Енергопродуктивність рослин - 40-60 (до 80) Гкал/га.

Сорго багаторічне (Sorghum almum Parodi.) належить до родини тонконогових. Рослина заввишки 230-300 см. Основне стебло і всі бічні пагони зверху закінчуються волоттю. Листки довголанцетні, 60-80 см завдовжки, 3-5 см завширшки. Чисельність їх на рослині коливається від 18 до 26 штук. Листки основою охоплюють стебло наполовину. Суцвіття - волоть довжиною 40-45 см. Насіння - видовжене, коричневочорне. Маса 1000 штук - 8,5-9,0 грамів. Коренева система добре розвинена і проникає в грунт на глибину 2,0-2,5 м. Під час посухи здатна розвивати вторинне коріння. Оптимальні строки сівби - I-II декада травня, коли грунт прогрівається на глибину $10 \mathrm{~cm}$ до $12-14{ }^{\circ} \mathrm{C}$. Польова схожість насіння становить 75-80 \%. Оптимальна температура для розвитку - плюс $18-25^{\circ} \mathrm{C}$.

Урожайність зеленої маси на початку формування волоті забезпечує 30-35 т/га, в період цвітіння - 45-50 т/га і в період плодоношення - 6575 т/га, насіння становить 1,5-1,7 т/га. Вихід сухої фітосировини - 11-14 т/га. Енергетична цінність становить 3750-3810 ккал/кг.

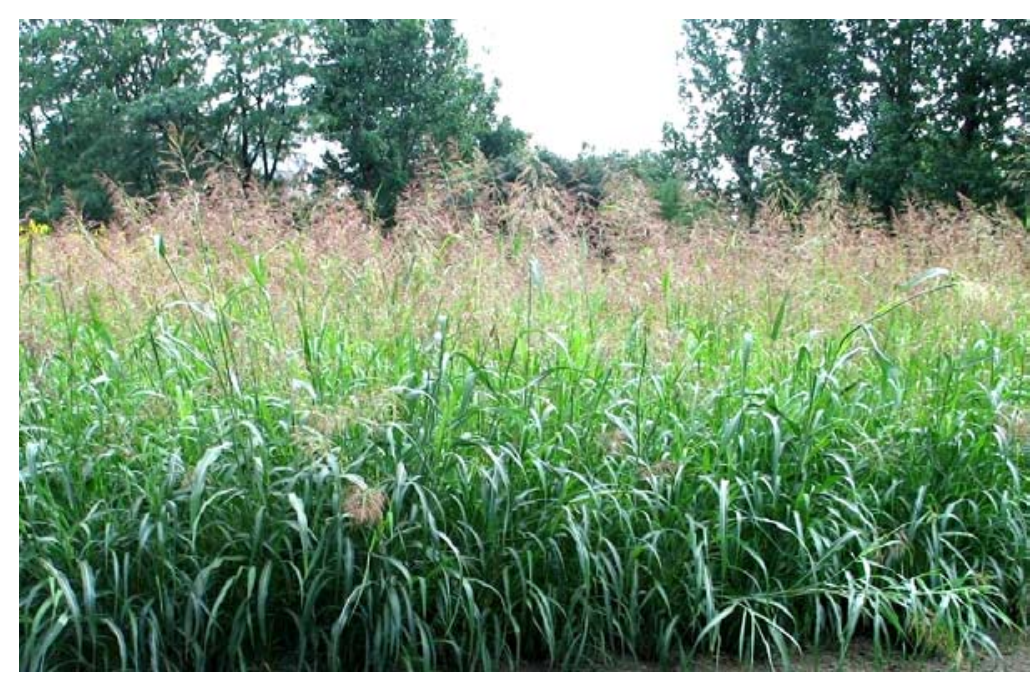

Puс. 4. Багаторічне сорго (Sorghum almum Parodi.) 


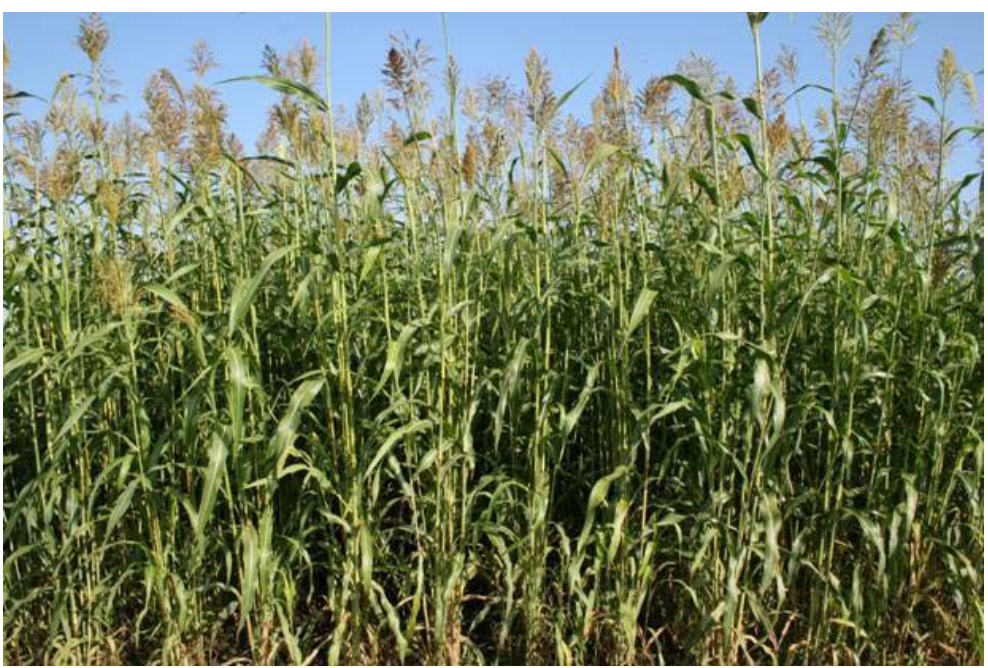

Puc. 5. Сорго цукрове (Sorghum saccharatum (L.) Moench.)

Сорго цукрове (Sorghum saccharatum (L.) Moench.) - однорічна трав'яниста рослина (яра форма). Рослини досягають висоти до 300 см. Стебло пряме, діаметр біля основи 13-36 мм. Число міжвузлів на стеблі, залежно від висоти, коливається від 5-9 до 25. Листки довголанцетні, великі, довжиною 50-100 см і шириною - 1м6 см, у деяких форм - до 10 см та більше. Суцвіття - волоть довжиною 15-60 см різної форми (розлога, стисла, комова та ін.). Зерно сорго - голе або плівчасте, кулястої, подовжено-овальної, яйцевидної форми, білого, жовтого, коричневого, чорного забарвлення. Маса 1000 зернин - 27-33 (до 40) г. Коренева система мичкувата, сильно розвинена, заглиблюється в грунт до 150-200 см.

Як однорічник сорго проходить всі етапи органогенезу за один рік. Проходить наступні фази розвитку: сходи, кущіння, вихід у трубку, викидання волоті, цвітіння, молочно-воскова стиглість і достигання. Цвітіння проходить в липнісерпні, достигання - 3 другої половини серпня до кінця вересня. Вегетаційний період - 145-155 діб.

Урожайність фітосировини - 60-120 т/га, насіння - 900-1800 кг/га. Енергопродуктивність рослин - 35-70 (до 100) Гкал/га.

На основі багаторічних досліджень визначено, що потенціал урожайності енергетичних культур, поряд з їхніми видовими особливостями, реакцією на грунтово-кліматичні умови, залежить від агрохімічних властивостей грунту, способів його обробітку, застосовування добрив, біопрепаратів, строків та способів сівби / висаджування, догляду за рослинами, специфіки збирання врожаю, та інших факторів.

Характеристика енергетичних культур за потенціалом урожайності та періодом надходження фітосировини залежно від температурного режиму і кількості опадів за агрокліматичними зонами наведена нижче (табл., рис. 6).

Узагальнення результатів досліджень дозволило провести порівняння за періодом надходження біомаси енергетичних культур (рис. 6).

Порівняльна характеристика енергетичних культур за періодом надходження біомаси дає можливість стверджувати, що за правильного підходу в менеджменті посівів, урожайність сухої маси (сировини для біопалива: твердого, рідкого та газоподібного) - від 10 до 15 т/га, можливо стабільно отримувати протягом тривалого часу - iз серпня вересня попереднього року по лютий - березень наступного року.

Відповідно до агрокліматичного районування в Україні є зональні особливості підбору сортименту та технології вирощування сільськогосподарських і енергетичних культур. У зв'язку 3 чим зроблено спробу розподілу місць вирощування злакових енергетичних культур на території України з урахуванням біологічних особливостей рослин (див. табл.). 3 урахуванням морфолого-біологічних особливостей, відношенням рослин до температурного режиму та кількості опадів за вегетаційний період енергетичні культури родини тонконогових в Україні доцільно розміщувати наступним чином: арундо тростинний, міскантус гігантський та просо прутоподібне - зона Полісся, міскантус гігантський, просо прутоподібне, сорго багаторічне та сорго цукрове - Лісостеп, просо прутоподібне, сорго багаторічне та сорго цукрове - Степ України. Поряд із цим, за дотримання відповідних умов зрошення у степовій зоні можна вирощувати також різні культури роду міскантус. 


\section{Порівняльна характеристика енергетичних культур за урожайністю зеленої маси та виходом сухої речовини залежно від умов вирощування}

\begin{tabular}{|l|c|c|c|c|c|}
\hline \multicolumn{1}{|c|}{ Енергетична культура } & $\begin{array}{c}\text { Темпе- } \\
\text { ратура, } \\
{ }^{\circ} \mathrm{C}\end{array}$ & $\begin{array}{c}\text { Кількість } \\
\text { опадів, } \\
\text { мм }\end{array}$ & $\begin{array}{c}\text { Агрокліма- } \\
\text { тична зона }\end{array}$ & $\begin{array}{c}\text { Урожайність } \\
\text { зеленої маси, } \\
\text { т/га }\end{array}$ & $\begin{array}{c}\text { Вихід сухої } \\
\text { речовини, т/га }\end{array}$ \\
\hline Арундо тростинний & $20-30$ & $>500$ & $\Pi^{*}$ & $50-150$ & - \\
\hline Міскантус гігантський & $20-30$ & $>500$ & П, Л & $60-150$ & $10-15$ \\
\hline Просо прутоподібне & $20-30$ & $400-500$ & П, Л, С & $43-70$ & $10-15$ \\
\hline Сорго багаторічне & $20-30$ & $400-500$ & Л, С & $65-75$ & $11-14$ \\
\hline Сорго цукрове & $>30$ & $<400$ & Л, С & $60-120$ & - \\
\hline
\end{tabular}

* Примітка: П - Полісся, Л - Лісостеп, С - Степ.

\begin{tabular}{|c|c|c|c|c|c|c|c|c|c|c|c|c|c|c|c|c|}
\hline \multirow{2}{*}{ Культура } & \multicolumn{4}{|c|}{2013 рік } & \multicolumn{4}{|c|}{2014 рік } & \multicolumn{4}{|c|}{2015 рік } & \multicolumn{4}{|c|}{2016 рік } \\
\hline & $\mathrm{B}^{*}$ & л & $\mathrm{o}$ & 3 & B & л & o & 3 & B & л & o & 3 & В & л & o & 3 \\
\hline \multicolumn{17}{|l|}{ Арундо тростинний } \\
\hline \multicolumn{17}{|c|}{ Міскантус гігантський } \\
\hline \multicolumn{17}{|c|}{ Просо прутоподібне } \\
\hline \multicolumn{17}{|l|}{ Сорго багаторічне } \\
\hline \multirow{2}{*}{\multicolumn{17}{|c|}{ Сорго цукрове }} \\
\hline & & & & & & & & & & & & & & & & \\
\hline & \multicolumn{8}{|c|}{ - сівба / висаджування } & \multicolumn{8}{|c|}{ - догляд за рослинами } \\
\hline & & \multicolumn{15}{|c|}{ - збирання врожаю } \\
\hline
\end{tabular}

Рис. 6. Логістичний ланцюг вирощування, догляду за рослинами, збирання врожаю злакових енергетичних культур, 2013-2016 рр.

* Примітка: в - весняний період, л - літній період, о - осінній період, з - зимовий період.

Висновки. За відношенням до грунтовокліматичних умов України енергетичні культури досить різняться. Це пов'язано з їхнім походженням, біологічними особливостями, пристосувальними реакціями при інтродукції рослин та агротехнічними вимогами вирощування.

На Поліссі грунтово-кліматичні умови найбільш відповідають біологічним особливостям і сприятливі для вирощування арундо тростинного та міскантусу гігантського. Умови Лісостепу

\section{БІБЛІОГРАФІЯ}

1. Атлас енергетичного потенціалу нетрадиційних та відновлюваних джерел енергії. - К., 2016. - 54 c.

2. Гелетуха Г. Г. Перспективи вирощування та використання енергетичних культур в Україні / Г. Г. Гелетуха, Т. А. Железна, О. В. Трибой. Київ, 2014. - 33 с.

3. Доспехов Б. А. Методика полевого опыта (с основами статистической обработки результатов исследований) / Б. А. Доспехов. - Изд. 5-е, перераб. и доп. - М. : Агропромиздат, 1985. - 351 с.

4. Енергетична стратегія України на період до та Степу більш прийнятні для проса прутоподібного, сорго багаторічного та сорго цукрового.

3-поміж злакових енергетичних культур найбільший потенціал за врожайністю сухої маси мають арундо тростинний, міскантус гігантський. Дещо меншу продуктивність мають сорго багаторічне та просо прутоподібне за багаторічного циклу вирощування в грунтовокліматичних умовах, що відповідають їх біологічним особливостям.

2030 року // Інформаційно-аналітичний бюлетень «Відомості Міністерства палива та енергетики України». Спеціальний випуск. - 2006. $113 \mathrm{c}$.

5. Енергетичні культури для виробництва біопалива : довідник / В. Л. Курило, М. І. Кулик. Полтава, 2017. - $74 \mathrm{c}$.

6. Сщенко В. О. Основи наукових досліджень в агрономії / [В. О. Сщенко П. Г. Копитко, В. П. Опришко, та ін.]. - К.: Дія, 2005. -288 с.

7. Закон України від 20.11.2012 p. № 5485-VI. «Про внесення змін до Закону України «Про 


\section{СІЛЬСЬКЕ ГОСПОДАРСТВО. РОСЛИННИЦТВО}

електроенергетику» щодо стимулювання виробництва електроенергії 3 альтернативних джерел енергії».

8. Закон України про внесення змін до Закону України «Про альтернативні джерела енергії» щодо віднесення теплових насосів до обладнання, яке використовує відновлювані джерела енергії / Відомості Верховної Ради, 2017, № 1, ст.1.

9. Калетнік Г. М. Розвиток ринку біопалив в Україні : моногр. / Г. М. Калетнік ; рец. М. Й. Малік. - К.: Аграрна наука, 2008. - 464 с.

10. Котов М. И. Определитель высших растений Украины / М. И. Котов, Ю. Н. Прокудин, А. И. Барбарич. - [2-е изд., стереот., с незнач. доп. и испр.]. - К. : Фитосоциоцентр, Акад. наук Украинской ССР, Ин-т ботаники им. Н. Г. Холодного, 1999. - 548 с.

11. Кулик М. І. Довідник: ботаніко-біологічна характеристика, особливості вирощування та використання енергетичних культур. Частина перша: світчграс / Максим Іванович Кулик. Полтава, 2014. - 130 с.

12. Кулик M. I. Енергетичні культури: альбом / М. І. Кулик. - Полтава, 2017. - 38 с.

13. Курило В. Л. Біоенергетика в Україні: стан та перспективи розвитку / В. Л. Курило, М. В. Роїк, О. М. Ганженко // Біоенергетика. - 2013. Вип. № 1. - С. 5-10.

14. Курило В. Л. Міскантус - перспективна енергетична культура для виробництва біопалива / В. Л. Курило, М. Я. Гументик, В. М. Квак // Агробіологія : зб.наук.праць Білоцерківського НАУ, 2010. - № 4 (80). - С. 62-66.

15. Методи визначення якості. ДСТУ 41382002. Насіння сільськогосподарських культур [введ. 3 01.01.2004 р.]. - К.: Держспоживстандарт України, 2003. - 173 с.

16. Методика узагальненої оцінки технічнодосяжного енергетичного потенціалу біомаси / [В. О. Дубровін, Г. А. Голуб, С. В. Драгнєв, та ін.]. - К.: ТОВ «Віолпринт», 2013. - 25 с.

17. Мороз О. В. Світчграс як нова фітоенергетична культура / [О. В. Моро3, В. М. Смірних, В. Л. Курило та ін.] //Цукрові буряки. - 2011. №3. - С. 12-14.

18. Морозов Р. В. Оцінка біоенергетичного потенціалу рослинних відходів та енергетичних культур у сільському господарстві / Р. В. Морозов, С. М. Федорчук // Науковий вісник Херсонського державного університету, 2015. - Випуск 10. - Частина 3. - С. 111-117.
19. Определитель высших растений Украины / Акад. наук Украинской ССР ; Ин-т ботаники им. Н. Г. Холодного // М. И. Котов, Ю. Н. Прокудин, А. И. Барбарич. - 2-е изд., стереот., с незнач. доп. и испр. - К. : Фитосоциоцентр, 1999. - 548 с.

20. Постанова НКРЕ «Про затвердження Порядку встановлення, перегляду та припинення дії «зеленого» тарифу для суб'єктів господарської діяльності», від 02.11.2012. - № 1421.

21. Рахметов Д. Б. Міскантус в Україні: інтродукція, біологія, біоенергетика / Д. Б. Рахметов, Т. О.Щербакова, С. Д. Рахметов. - Київ : Фітосоціоцентр, 2015. - 158 с.

22. Рахметов Д. Б. Теоретичні та прикладні аспекти інтродукції рослин в Україні / Д. Б. Рахметов. - К.: Аграр Медіа Груп, 2011. - 398 с.

23. Рахметов Д. Б. Panicum virgatum L. - перспективний інтродуцент у Національному ботанічному саду ім. М. М. Гришка НААН України / Д. Б. Рахметов, О. М. Вергун, С. О. Рахметова // Інтродукція рослин. - Вип. 3(63), 2014. - С. 412.

24. Роїк M. В. Ефективність вирощування високопродуктивних енергетичних культур / [М. В. Роїк, В. Л. Курило, М. Я. Гументик та ін.] // Вісник Львівського національного аграрного університету. - 2011. - №15(2). - С.85-90.

25. Роик H. B. Результаты интродукции проса прутьевидного в растениеводство Украины / Н. В. Роик, Г. С. Гончарук, С. Н. Мандровская // Сахарная свекла. - Вып. №7, 2016. - С. 42-45.

26. Kulyk M. Methods of calculation productivity phytomass switchgrass in Ukraine / M. Kulyk, W. Elbersen. - Poltava, 2012. - 10 p.

27. Rossa B, Tuaers A. V., Naidoo $G$, von Willert D. J. (1998). Arundo donax L. (Poaceae) - a $\mathrm{C}_{3}$ species with unusually high photosynthetic capacity. Botanica Acta. 111 : 216-21.

28. Saltonstall K., Lambert A., Meyerson L.A. (2010). Genetics and reproduction of common (Phragmites australis) and giant reed (Arundo donax). Invasive Plant Sci. Manag. 3 : 495-505.

29. Spencer D. F., Ksander G. G. (2006). Estimate Arundo donax ramet recruitment using degree-day based equation. Aquat. Bot. 85 : 282-288.

30. Switchgrass Ukraine : overview of switchgrass research and guidelines / Elbersen, H.W.; Kulyk, M.; Poppens, at all. Wageningen : Wageningen UR Food \& Biobased Research. -26 p. 